\title{
Functional Cloning and Expression of the Schizophyllum commune Glucuronoyl Esterase Gene and Characterization of the Recombinant Enzyme
}

\author{
Dominic W. S. Wong, ${ }^{1}$ Victor J. Chan, ${ }^{1}$ Amanda A. McCormack, ${ }^{1}{ }^{\prime a ́ n ~ H i r s c h, ~}{ }^{2}$ and Peter Biely ${ }^{2}$ \\ ${ }^{1}$ Western Regional Research Center, USDA-ARS, Albany, CA 94710, USA \\ ${ }^{2}$ Institute of Chemistry, Slovak Academy of Sciences, Dúbravská Cesta 9, 84538 Bratislava, Slovakia \\ Correspondence should be addressed to Dominic W. S. Wong, dominic.wong@ars.usda.gov
}

Received 19 March 2012; Revised 7 May 2012; Accepted 9 May 2012

Academic Editor: Henrik Brinch-Pedersen

Copyright ( $) 2012$ Dominic W. S. Wong et al. This is an open access article distributed under the Creative Commons Attribution License, which permits unrestricted use, distribution, and reproduction in any medium, provided the original work is properly cited.

\begin{abstract}
The gene encoding Schizophyllum commune glucuronoyl esterase was identified in the scaffold 17 of the genome, containing two introns of $50 \mathrm{bp}$ and $48 \mathrm{bp}$, with a transcript sequence of $1179 \mathrm{bp}$. The gene was synthesized and cloned into Pichia pastoris expression vector pGAPZ $\alpha$ to achieve constitutive expression and secretion of the recombinant enzyme in soluble active form. The purified protein was $53 \mathrm{kD}$ with glycosylation and had an acidic $\mathrm{pI}$ of 3.7. Activity analysis on several uronic acids and their derivatives suggests that the enzyme recognized only esters of 4-O-methyl-D-glucuronic acid derivatives, even with a 4-nitrophenyl aglycon but did not hydrolyze the ester of D-galacturonic acid. The kinetic values were $K_{m} 0.25 \mathrm{mM}, V_{\max } 16.3 \mu \mathrm{M} \cdot \mathrm{min}^{-1}$, and $k_{\text {cat }}$ $9.27 \mathrm{~s}^{-1}$ with 4-nitrophenyl 2- $O$-(methyl 4- $O$-methyl- $\alpha$-D-glucopyranosyluronate)- $\beta$-D-xylopyranoside as the substrate.
\end{abstract}

\section{Introduction}

In the current schemes of biomass conversion, pretreatment with enzyme hydrolysis recovers only about $85 \%$ of the theoretical yield for the available sugars [1]. Development of a cost-competitive process is hampered by the lack of knowledge on the breakdown of covalent cross-linkages connecting cellulose, hemicellulose, and lignin in plant cell walls. As much as $90 \%$ of the lignin in woody plants might be covalently linked to polysaccharides [2]. The types of covalent lignin-carbohydrate linkages have been proposed to include lignin alcohol esters, ethers, and phenyl glycosides [3-5]. The wood-rotting fungus Schizophyllum commune has been shown to produce a glucuronoyl esterase ( $S c \mathrm{GE}$ ), which cleaves substrate mimics of ester bonds between lignin alcohols and glucuronoxylan [6]. Other carbohydrate esterases, acetylxylan esterases, feruloyl esterases, and pectin methylesterases, did not act on these substrates. GE enzymes were subsequently isolated from other source microorganisms, including Hypocrea jecorina, Phanerochaete chrysosporium, and Sporotrichum thermophile [7-9]. In this paper, the putative cDNA gene of glucuronoyl esterase in the genome of the original source microorganism, Schizophyllum commune was identified, synthesized, cloned, and expressed in Pichia pastoris. The recombinant enzyme ( $\mathrm{rScGE}$ ) was purified and its enzyme action characterized on uronic acid substrates and their derivatives.

\section{Materials and Methods}

2.1. Materials and Strains. The pGAPZ $\alpha-\mathrm{A}$ vector, strain SMD1168, Zeocin, protein extraction reagent, precast gel, protein standards and staining kits were purchased from Invitrogen (San Diego, CA, USA). Gene DNA synthesis was performed by EZBiolab (Carmel, IN, USA), and primers and oligos were synthesized by Elim Biotech (Hayward, CA, USA). Restriction enzymes and DNA modifying enzymes were obtained from New England Biolab (Beverly, MA, USA). Plasmid prep, DNA extraction, and PCR minicolumns were obtained from Qiagen (Valencia, CA, USA). NiSepharose resin was purchased from GE Healthcare (Piscataway, NJ, USA). Coomassie Plus Protein Assay Reagent, 
$\mathrm{N}$-glycosidase F, and Glycoprotein Deglycosylation Kit were purchased from Pierce (Rockford, IL, USA).

2.2. Gene-Vector Construction. The ScGE gene was synthesized to include 1179 nucleotides of the CDS (encoding all 393 amino acids except the start Met), a 5'EcoRI site and a $3^{\prime} X b a \mathrm{I}$ site. The gene was cloned into Pichia pastoris expression vector $\mathrm{pGAPZ} \alpha$-A by restriction digest and ligation using standard methods. For transformation, the DNA-vector construct was linearized at the unique BspHI site, gel-isolated, and recovered.

2.3. Transformation of Pichia pastoris. Competent yeast cells were prepared using the EasyComp Kit (Invitrogen). For each transformation, $2 \mu \mathrm{g}$ of linearized DNA was mixed with $50 \mu \mathrm{L}$ of competent cells of SMD1168, a protease-deficient strain of Pichia pastoris, and chemically transformed following the manufacturer's protocol. Transformants were plated on YPD agar plates containing $1000 \mu \mathrm{g} / \mathrm{mL}$ Zeocin antibiotic and incubated at $30^{\circ} \mathrm{C}$ for three days. All colonies were restreaked on YPD Zeocin to obtain pure isolates.

2.4. Expression and Purification of the Recombinant Glucuronoyl Esterase. A single yeast colony was used to inoculate $10 \mathrm{~mL}$ of buffered complex $2 \%$ glucose media ( $1 \%$ yeast extract, $2 \%$ peptone, $100 \mathrm{mM}$ potassium phosphate, $\mathrm{pH} 6.0$, $1.34 \%$ yeast nitrogen base, $4 \times 10^{-5} \%$ biotin, and $2 \%$ glucose) and shaken at $225 \mathrm{rpm}$ and $30^{\circ} \mathrm{C}$ overnight. Overnight culture of $5 \mathrm{~mL}$ was diluted into $500 \mathrm{~mL}$ of media $(1: 100)$ in a 2-liter baffled flask and shaken at $225 \mathrm{rpm}$ and $30^{\circ} \mathrm{C}$ for 5 days. The culture was centrifuged $10 \mathrm{~min}$ at $10,000 \times \mathrm{g}$ and passed through a $0.45 \mu \mathrm{m}$ polyethylene sulfone filter. The clarified culture supernatant was concentrated using a PelliconXL device with a Biomax10 membrane on a Labscale TFF pump (Millipore) and buffer exchanged to $0.3 \mathrm{M} \mathrm{NaCl}$, $50 \mathrm{mM}$ Na phosphate, $\mathrm{pH}$ 7.0. The concentrated supernatant was applied to an AKTA prime FPLC fitted with a HisTrap $\mathrm{HP}$ column at a flow rate $0.3 \mathrm{of} \mathrm{mL} / \mathrm{min}$ and eluted in a linear gradient of 0 to $200 \mathrm{mM}$ imidazole over $30 \mathrm{~mL}$. The protein peak was eluted approximately between 50 and $125 \mathrm{mM}$ imidazole. Fractions were analyzed on a $4-12 \%$ BisTris NuPAGE run at $200 \mathrm{~V} 50 \mathrm{~min}$. Pooled fractions were concentrated and buffer exchanged to $10 \%$ glycerol, $25 \mathrm{mM}$ Na phosphate, $\mathrm{pH} 6.0$ buffer.

2.5. Enzyme Activity Assay. A qualitative assay of glucuronoyl esterase by TLC was performed using the following substrates: (I) methyl 4-O-methyl- $\alpha$-D-glucopyranuronate, (II) methyl D-glucopyranuronate, (III) 4-nitrophenyl methyl$\beta$-D-glucuronide, methyl D-galactopyranuronate, and (IV) methyl-D-galacturonate (Figure 1). Enzyme reactions were performed by incubating $1 \mu \mathrm{g}$ of purified enzyme with $20 \mathrm{mM}$ of substrate in $50 \mathrm{mM}$ Na phosphate buffer, $\mathrm{pH} 6.0$, at $30^{\circ} \mathrm{C}$ for $20 \mathrm{~min}$. The reaction mixture was spotted on Silica gel 60 TLC plates developed in ethyl acetate: acetic acid:1propanol: formic acid: water $(25: 10: 5: 1: 15)$ and visualized with $N$-(1-naphthyl) ethylenediamine dihydrochloride) $[10,11]$.
The enzyme activity was quantified by HPLC using compound V: 4-nitrophenyl 2-O-(methyl 4-O-methyl- $\alpha$ $\mathrm{D}$-glucopyranosyluronate)- $\beta$-D-xylopyranoside as the substrate (Figure 1, structure V). The substrate was used at concentrations from 0.08 to $0.4 \mathrm{mM}$ in $50 \mathrm{mM}$ Na phosphate buffer, $\mathrm{pH}$ 6.0, with enzyme added at $0.157 \mu \mathrm{M}$. Equal volume of cold $1 \mathrm{M} \mathrm{Na}$ acetate, $\mathrm{pH} 4.5$ was added to stop the reaction, and the sample was analyzed by a HPLC system fitted with a UV detector at $300 \mathrm{~nm}$ using a C18 column with water: formic acid: acetonitrile $(7: 1: 2)$ as the solvent at a flow rate of $0.3 \mathrm{~mL} / \mathrm{min}$. The kinetic values were obtained by nonlinear regression analysis of the MichaelisMenten plot of $v$ as a function of [s]. A Lineweaver-Burk plot was derived from transformation based upon nonlinear regression analysis that reflects the best possible estimates.

2.6. Deglycosylation. The $\mathrm{rScGE}$ protein was denatured by heating at $100^{\circ} \mathrm{C}$ for $10 \mathrm{~min}$ in $\mathrm{SDS} / \beta$-mercaptoethanol $\mathrm{Na}$ phosphate buffer, $\mathrm{pH}$ 7.0, followed by addition of $\mathrm{N}$-glycosidase $\mathrm{F}$ as recommended by the supplier of the glycosylation kit. The reaction mixture was incubated at $37^{\circ} \mathrm{C}$ for $1 \mathrm{hr}$, before running SDS-PAGE. For carbohydrate estimation, $\mathrm{rScGE}$ was oxidized by sodium metaperiodate to aldehydes, which reacted with glycoprotein detection reagent to form a purple product with maximum absorbance at $550 \mathrm{~nm}$.

2.7. Bioinformatics. Vector NTI and Geneous were used for sequence analysis and construction. Homology modeling was accomplished by the use of Swiss Model [12]. GraphPad Prism 4 was used for kinetic analysis.

\section{Results}

The putative gene sequence (jgi Schcol 238770 fgenesh2_pg.17_\#_99) for Schizophyllum commune glucuronoyl esterase was found to locate at scaffold 17 of the genome (MW_003315656), containing two introns of $50 \mathrm{bp}$ and $48 \mathrm{bp}$, with a transcript (coding) sequence of $1179 \mathrm{bp}$ (http:// genome.jgi-psf.org/). A transcription element TATA box within the promoter region, and a polyadenylation sequence AACAAAA at $\sim 200$ bp downstream of the stop codon were identified. The structural gene encodes a protein of 393 amino acids, with a predicted molecular mass of $41.8 \mathrm{kD}$ and a pI of 4.1. The $\mathrm{N}$-terminal 19 residues form a signal peptide with the cleavage site predicted between Ala19 and Gln20. Extensive blast search of the $S$. commune genome with the highly conserved regions of the known GE enzymes did not reveal a second GE gene in the genome.

The translated sequence of the identified S. commune GE gene shows an exact match with the peptide sequence obtained by Edman analysis of the previously biochemically characterized ScGE (DTPATVSGYSNSALPDPF). There is also an exact match with the internal tryptic peptide (AGALEPRVALTLPQE) of the native $S c$ GE enzyme as well [7]. Blast search revealed close alignment with, $H$. jecorina Cip2 (AAP57749) and P. chrysosporiumge1 (e_gwh2.18.77.1), showing similarities of $59.0,67.1 \%$ and identities of 51.1 , 
<smiles>COC(=O)C1OC(O)C(O)C(O)C1O</smiles>

(I) Methyl 4-O-methylD-glucopyranuronate<smiles>COC(=O)C1OC(O)C(O)C(O)C1O</smiles>

(II) Methyl-D-glucopyranuronate

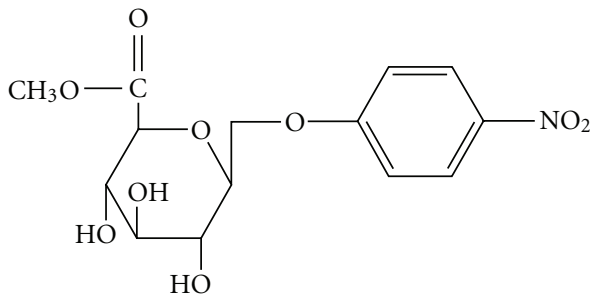

(III) 4-Nitrophenyl methyl- $\beta$-D-glucuronide<smiles>COC(=O)C1OC(O)C(O)C2OC1C2O</smiles>

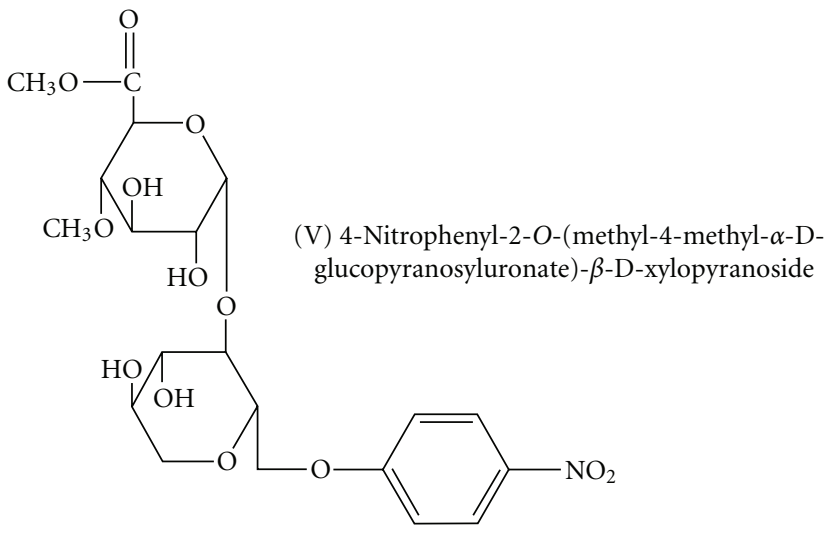

FIGURE 1: Substrate compounds used for activity and kinetic measurements [10].

(1) S. commune GE

(2) H. jecorina

(3) P. chrysosporium

(1) S. commune GE

(2) H. jecorina

(3) P. chrysosporium

(1) S. commune GE

(2) H. jecorina

(3) P. chrysosporium

(1) S. commune GE

(2) H. jecorina

(3) P. chrysosporium

(1) S. commune GE

(2) H. jecorina

(3) P. chrysosporium

(1) S. commune GE

(2) H. jecorina

(3) P. chrysosporium

(1) S. commune GE

(2) H. jecorina

(3) P. chrysosporium

IV) Methyl D-galactopyranuronate

Figure 2: Multiple sequence alignment of S. commune (XP_003026289), H. jecorina (AAP57749), and P. chrysosporium (e_gwh2.18.77.1) glucuronoyl esterases using Geneious software.

$61.0 \%$, respectively (Figure 2 ). The ScGE sequence also shows $56.5 \%$ similarity and $48.1 \%$ identity with the recently reported $S$. thermophile enzyme [9].

The gene-vector ScGE-pGAPZ $\alpha$ cloned into the Pichia pastoris for expression consisted of $1176 \mathrm{bp}$ CDS (encoding all amino acids except the start Met), a 30 bp myc epitope tag, an 18 bp polyhistidine tag sequence, and a Zeocin resistance gene for selection (Figure 3). The total nucleotide sequence of the construct translates to a molecular mass of $41.6 \mathrm{kD}$. The gene vector was transformed into SMD1168, a protease deficient strain, for expression of the recombinant protein. The $\mathrm{rScGE}$ was purified from culture supernatant by ultrafiltration followed by Ni-Sepharose affinity chromatography. The purified protein showed an N-terminal sequence of 

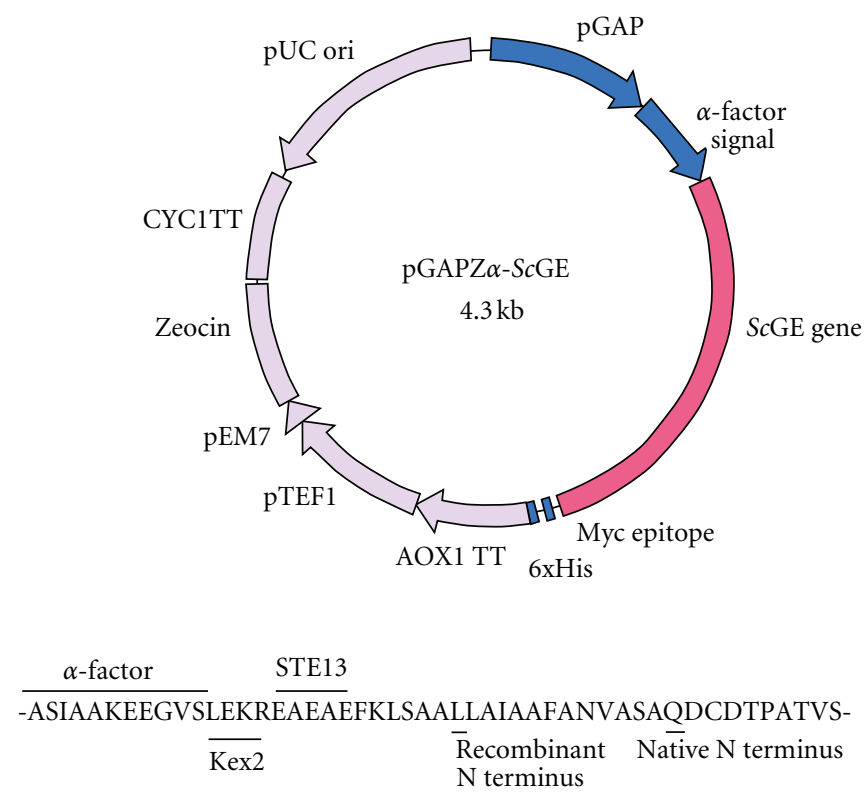

FIGURE 3: Construction scheme of the recombinant plasmid pGAPZ $\alpha$-ScGE. Below shows sequence details of the $\alpha$-factor junction with the $\mathrm{N}$-terminus.

LSAALLAIAAFA indicating that the vector $\alpha$-factor signal was cleaved at three amino acid residues after the Ste13 protease site (Figure 3).

SDS-PAGE of $\mathrm{rScGE}$ showed a band $\geq 53 \mathrm{kD}$, which was larger than predicted from the nucleotide sequence (Figure 4). Isoelectrofocusing revealed that the $\mathrm{rScGE}$ was in multiple forms with the major band having a pI of 3.7. The band patterns on both the SDS-PAGE and IEF gels suggested that the protein was glycosylated. Treatment of $\mathrm{rScGE}$ with $N$-glycosidase-F caused the band sharpened and shifted in electrophoretic migration to $46 \mathrm{kD}$, closer to the calculated size (Figure 5). Results from periodate oxidation suggested that the protein contained $\sim 1.4 \%$ carbohydrate content.

The $\mathrm{rScGE}$ enzyme tested for its activity on methyl esters of uronic acids and their glycosides (substrates I to V, Figure 1) showed catalytic properties using compounds I-V as substrates. The enzyme reactions were performed at $\mathrm{pH}$ 6.0 as the highest value, because the ester linkages become unstable under more alkaline conditions. The enzyme action on substrates I to IV was monitored by TLC, based on the migration $R_{f}$ difference between the methyl ester substrates and the deesterified product (Figure 6(a)). The enzyme reaction using substrate V was analyzed by HPLC (Figure 6(b)). The enzyme was not active on substrate IV, which contained an esterified galacturonic acid moiety instead of glucuronic acid as in the other four substrates.

The enzyme reaction on 4-nitrophenyl-2-O-(meth-yl4-O-methyl- $\alpha$-D-glucopyranosyluronate) $-\beta$-D-xylopyranoside (compound V) was quantified using HPLC, and the peak retentions were $14.5 \mathrm{~min}$ and $8.4 \mathrm{~min}$ for the ester substrate and the acid product, respectively. The kinetic values were determined with $K_{m} 0.25 \mathrm{mM}, V_{\max } 16.3 \mu \mathrm{M} \cdot \mathrm{min}^{-1}$, and $k_{\text {cat }} 9.27 \mathrm{~s}^{-1}$ (Figure 7).

\section{Discussion}

The S. commune GE gene was constitutively expressed and secreted from Pichia pastoris in soluble active form using the pGAPZ vector expression system. The pGAPZ vector consists of the strong promoter of the glyceraldehyde-3phosphate dehydrogenase gene, fused to an N-terminal peptide encoding the Saccharomyces cerevisiae $\alpha$-factor secretion signal. The use of methanol inducible vectors with various gene-vector constructions all resulted in negligible expression. It was also found that for the purification of the recombinant enzyme, a quick clarification of the culture by polyethylene sulfone filters followed by membrane ultrafiltration enhanced affinity binding in the Ni-Sepharose column and the recovery of the enzyme.

The structure of ScGE revealed by homology modeling shows a typical hydrolase $\alpha / \beta$ fold, as recently determined for the crystal structure of $H$. jecorina enzyme [13]. The molecule is structurally related to the BVU-4111 esteraselike protein found in Bacteroides vulgatus (3g8y). The BVU4111 protein structure is similar to Bacillus pumilus AXE (3fvt), Thermotoga maritima AXE, and Bacillus subtilis cephalosporin C deacetylase (lods), which are all CE7 serine-type esterases. However, sequence alignment reveals no obvious similarity between the GE enzymes and known AXEs.

The $\mathrm{rScGE}$ does not contain a CBM. This is in contrast to the native GE enzymes isolated from other microorganisms, including $H$. jecorina, $P$. chrysosporium, and $S$. thermophile, which consist of a carbohydrate-binding type 1 (CBM1) domain at the $\mathrm{N}$-terminus linked to the catalytic domain [7-9]. The existence of CBMs has been observed in various carbohydrases, including cellulases and hemicellulases, but not all carbohydrate active enzymes have acquired this type 


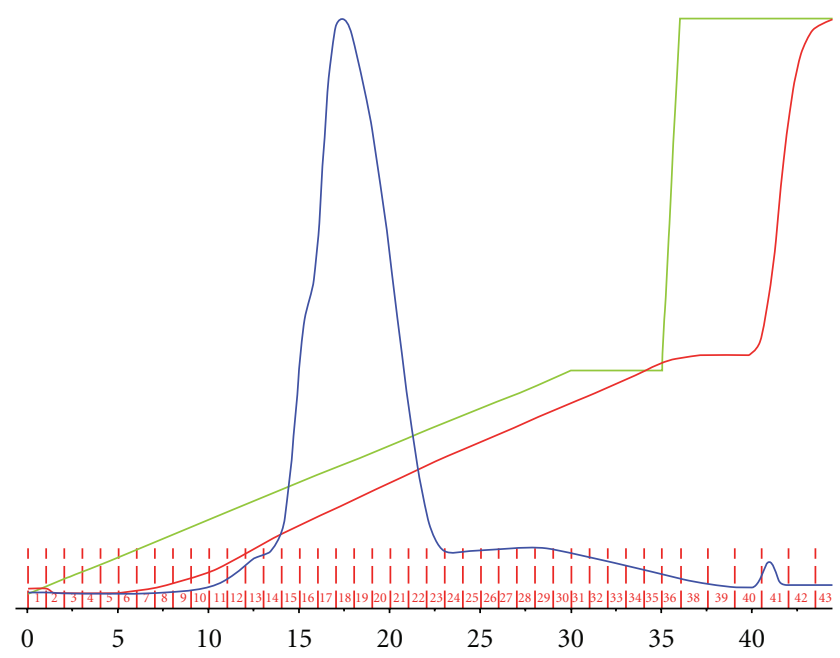

(a)

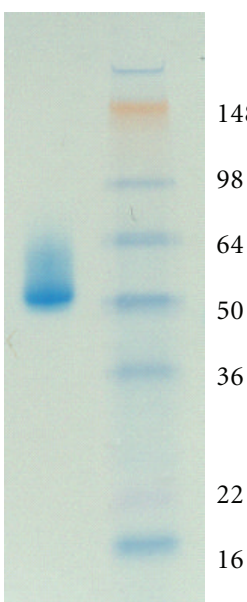

(b)
148

98

64

50

22

16

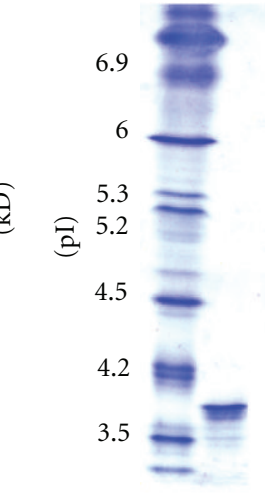

(c)
Figure 4: (a) Chromatogram of purification by Ni Sepharose column. Details described in "Methods" section. (b) SDS-PAGE on $40-12 \%$ Novex Bis-Tris gel. (c) IEF on Invitrogen pH 3-10 IEF gel.

of noncatalytic domain. The most recognized function of $\mathrm{CBM}$ is to facilitate the hydrolysis of insoluble polysaccharides. CBM1 structures typically consist of 4 conserved cysteines forming disulfide bonds (http://www.CAZY.org/). The number of aromatic residues and their precise spatial arrangement in the flat face of the type I CBD fold are critical for specific binding with the aromatic rings stacked onto the glucose ring of the cellulose structure [14]. It is not certain at present how the lack of a CBM in the $\mathrm{rScGE}$ enzyme would influence its biochemical action on insoluble substrates.

The glycosylation of $\mathrm{rScCE}$ was confirmed by $\mathrm{N}$ glycosidase treatment followed by SDS-PAGE. Two potential $N$-glycosylation sites are found at positions 103-106 (NNSI) and 168-171 (NASA) of the sequence. Glycosylation may potentially improve enzyme stability as reported in the literature for some enzymes $[15,16]$. The native $S c G E$ that was estimated to be $44 \mathrm{kD}$ did not seem to be glycosylated and had a pI of 3.5 [6]. The native enzymes isolated from $H$. jecorina and $P$. chrysosporium were not glycosylated, although

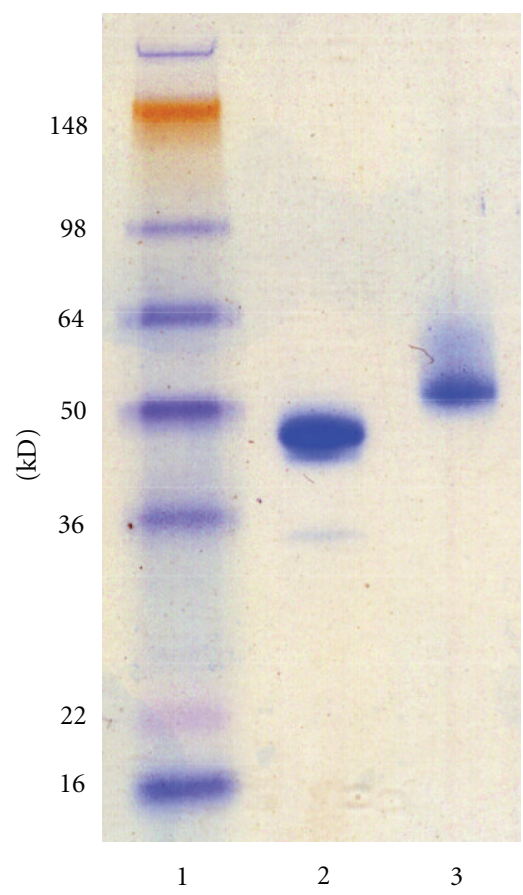

FIGURE 5: SDS-PAGE of rScGE (lane 3) and deglycosylated rScGE (lane 2). Deglycosylation reaction described in "Methods" section, performed on $4-12 \%$ Novex Bis-Tris gel, stained by Invitrogen Simply Blue SafeStain.

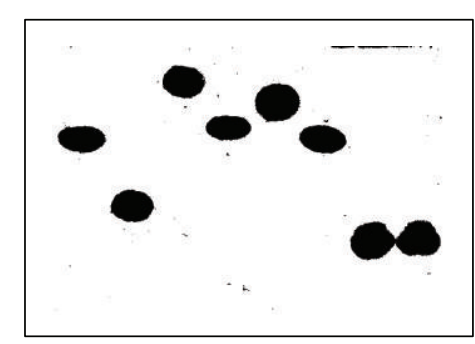

$\begin{array}{llllllll}1 \mathrm{a} & 1 \mathrm{~b} & 2 \mathrm{a} & 2 \mathrm{~b} & 3 \mathrm{a} & 3 \mathrm{~b} & 4 \mathrm{a} & 4 \mathrm{~b}\end{array}$

(a)

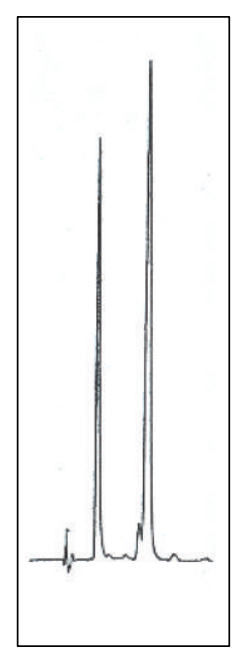

Peak 12

(b)
FIGURE 6: Separation of substrate and product components in reaction mixtures by (a) TLC: $1 \mathrm{a}, \mathrm{b}$ (substrate I \& product), 2a, b (II \& product), 3a, b (III \& product), 4a, b (IV \& product); (b) HPLC: peak 1, 2 for the acid (product) and ester of substrate $V$, respectively. Reaction conditions: $20 \mathrm{mM}$ substrate in $50 \mathrm{mM}$ sodium phosphate buffer, $\mathrm{pH}$ 6.0, $1 \mu \mathrm{g} \mathrm{rScGE}, 30^{\circ} \mathrm{C}, 30 \mathrm{~min}$. See details on TLC and HPLC runs in "Methods" section. 


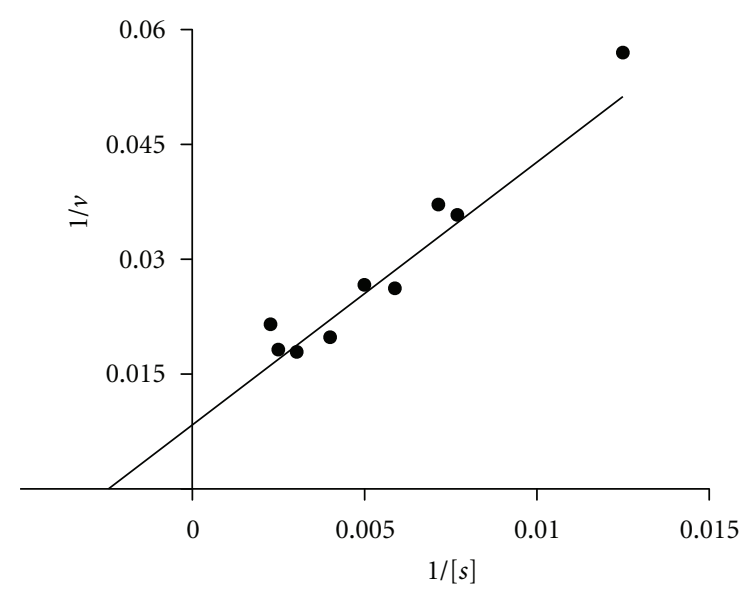

Figure 7: Lineweaver-Burk plot of $1 / v$ as a function of $1 /[\mathrm{s}]$. Substrate V was used at concentrations of 0.08 to $0.4 \mathrm{mM}$. The kinetic parameters were calculated by nonlinear regression analysis using GraphPad software.

putative glycosylation sites were identified in the sequences $[7,8]$. The glycosylation of the recombinant enzyme in the present study may well be the result of the posttranslational processing by the Pichia expression system. The acidic pI observed for $\mathrm{rScGE}$ and also for the native enzyme is in contrast to the other GE enzymes, which have pIs in the basic range. The significance of this disparity in the pI requires further investigation.

The $\mathrm{rScGE}$ showed similar action and kinetics on the substrates with functional properties representative of the native enzyme purified from $S$. commune. The $\mathrm{rScGE}$ hydrolyzed all the substrates containing D-glucuronic acid moiety. It did not hydrolyze methyl D-galactopyranuronate (substrate IV), suggesting the importance of the glucoconfiguration at $\mathrm{C} 4$ in substrate recognition. The result indicates that the enzyme recognized alkyl and arylalkyl esters of methyl-Dglucuronic acid only. It also provides indirect support that the enzyme specificity was on the ester bonds in substrates with mimics between glucuronoxylan and lignin alcohols. Unlike synthetic mimics, however, the ester bond in the natural substrate formed between the lignin alcohol and the C6 carboxylic group of the methylglucuronic acid entails a very bulky molecule. The synthetic substrates are close but not exact representation of the natural substrate. The physiological role of the enzyme on natural substrates has yet remained to be demonstrated. A recent work on the genome of Teredinibacter turnerae T7901 has identified a gene cluster of GH11-CBM5-GE15 encoding a multicatalytic enzyme with the GE15 glucuronoyl esterase combined with GH11xylanase, suggesting its important function in plant cell wall degradation [17]. It is envisioned that a large dose of the enzyme may be required to hydrolyze ester linkages between hemicellulosic uronic acids and lignin alcohols existing in large molecules in plant cell wall. The enzyme may also require collective action of other plant cell wall hydrolytic enzymes. The heterologous expression and production of active $\mathrm{rScCE}$ will facilitate further investigation in this direction.

\section{Acknowledgments}

Reference to a company and/or products is only for purposes of information and does not imply approval of recommendation of the product to the exclusion of others that may also be suitable. All programs and services of the USA Department of Agriculture are offered on a nondiscriminatory basis without regard to race, color, national origin, religion, sex, age, marital status, or handicap. J. Hirsch and P. Biely were supported by the Slovak Academy of Sciences Grant Agency VEGA Grant no. 2/0001/10.

\section{References}

[1] C. E. Wyman, B. E. Dale, R. T. Elander et al., "Comparative sugar recovery and fermentation data following pretreatment of poplar wood by leading technologies," Biotechnology Progress, vol. 25, no. 2, pp. 333-339, 2009.

[2] M. Lawoko, G. Henriksson, and G. Gellerstedt, "Structural differences between the lignin-carbohydrate complexes present in wood and in chemical pulps," Biomacromolecules, vol. 6, no. 6, pp. 3467-3473, 2005.

[3] T. J. Painter, "Residues of d-lyxo-5-hexosulopyranuronic acid in Sphagnum holocellulose, and their role in cross-linking," Carbohydrate Research, vol. 124, no. 1, pp. C18-C21, 1983.

[4] T. Imamura, T. Watanabe, M. Kuwahara, and T. Koshijima, "Ester linkages between lignin and glucuronic acid in lignincarbohydrate complexes from Fagus crenata," Phytochemistry, vol. 37, no. 4, pp. 1165-1173, 1994.

[5] T. Watanabe, J. Ohnishi, Y. Yamasaki, S. Kaizu, and T. Koshima, "Binding-site analysis of the ether linkages between lignin and hemicelluloses in lignin-carbohydrate complexes by DDQ-oxidation," Agricultural and Biological Chemistry, vol. 53, pp. 2233-2252, 1989.

[6] S. Spániková and P. Biely, "Glucuronoyl esterase-novel carbohydrate esterase produced by Schizophyllum commune," FEBS Letters, vol. 580, no. 19, pp. 4597-4601, 2006.

[7] X. L. Li, S. Špániková, R. P. de Vries, and P. Biely, "Identification of genes encoding microbial glucuronoyl esterases," FEBS Letters, vol. 581, no. 21, pp. 4029-4035, 2007.

[8] M. Ďuranová, S. Špániková, H. A. B. Wösten, P. Biely, and R. P. De Vries, "Two glucuronoyl esterases of Phanerochaete chrysosporium," Archives of Microbiology, vol. 191, no. 2, pp. 133-140, 2009.

[9] C. Vafiadi, E. Topakas, P. Biely, and P. Christakopoulos, "Purification, characterization and mass spectrometric sequencing of a thermophilic glucuronoyl esterase from Sporotrichum thermophile," FEMS Microbiology Letters, vol. 296, no. 2, pp. 178-184, 2009.

[10] M. Duranová, J. Hirsch, K. Kolenová, and P. Biely, "Fungal glucuronoyl esterases and substrate uronic acid recognition," Bioscience, Biotechnology and Biochemistry, vol. 73, no. 11, pp. 2483-2487, 2009.

[11] J. Hirsch, V. Langer, and M. Koóš, "Synthesis and molecular structure of methyl 4-O-methyl- $\alpha$-D- glucopyranuronate," Molecules, vol. 10, no. 1, pp. 251-258, 2005.

[12] K. Arnold, L. Bordoli, J. Kopp, and T. Schwede, "The SWISSMODEL workspace: a web-based environment for protein structure homology modelling," Bioinformatics, vol. 22, no. 2, pp. 195-201, 2006.

[13] P. R. Pokkuluri, N. E. C. Duke, S. J. Wood et al., "Structure of the catalytic domain of glucuronoyl esterase Cip2 from 
Hypocrea jecorina," Proteins: Structure, Function and Bioformatics, vol. 79, no. 8, pp. 2588-2592, 2011.

[14] M. L. Mattinen, M. Kontteli, J. Kerovuo et al., "Threedimensional structures of three engineered cellulose-binding domains of cellobiohydrolase I from Trichoderma reesei," Protein Science, vol. 6, no. 2, pp. 294-303, 1997.

[15] O. Olsen and K. K. Thomsen, "Improvement of bacterial $\beta$ glucanase thermostability by glycosylation," Journal of General Microbiology, vol. 137, no. 3, pp. 579-585, 1991.

[16] S. E. Clark, E. H. Muslin, and C. A. Henson, "Effect of adding and removing $\mathrm{N}$-glycosylation recognition sites on the thermostability of barley $\alpha$-glucosidase," Protein Engineering, Design and Selection, vol. 17, no. 3, pp. 245-249, 2004.

[17] J. C. Yang, R. Madupu, A. S. Durkin et al., "The complete genome of Teredinibacter turnerae T7901: an intracellular endosymbiont of marine wood-boring bivalves (shipworms)," PLoS ONE, vol. 4, no. 7, Article ID e6085, 2009. 

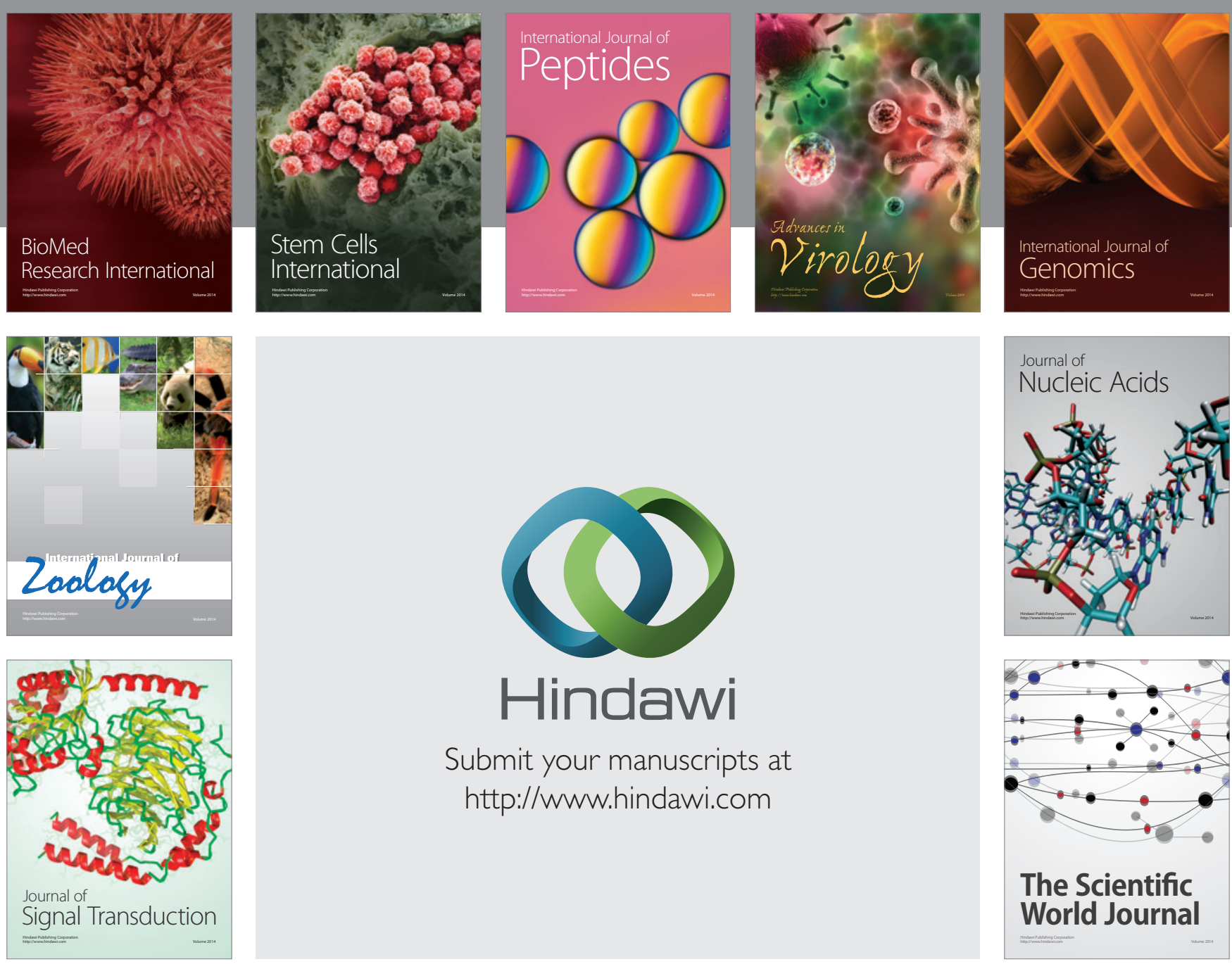

Submit your manuscripts at

http://www.hindawi.com
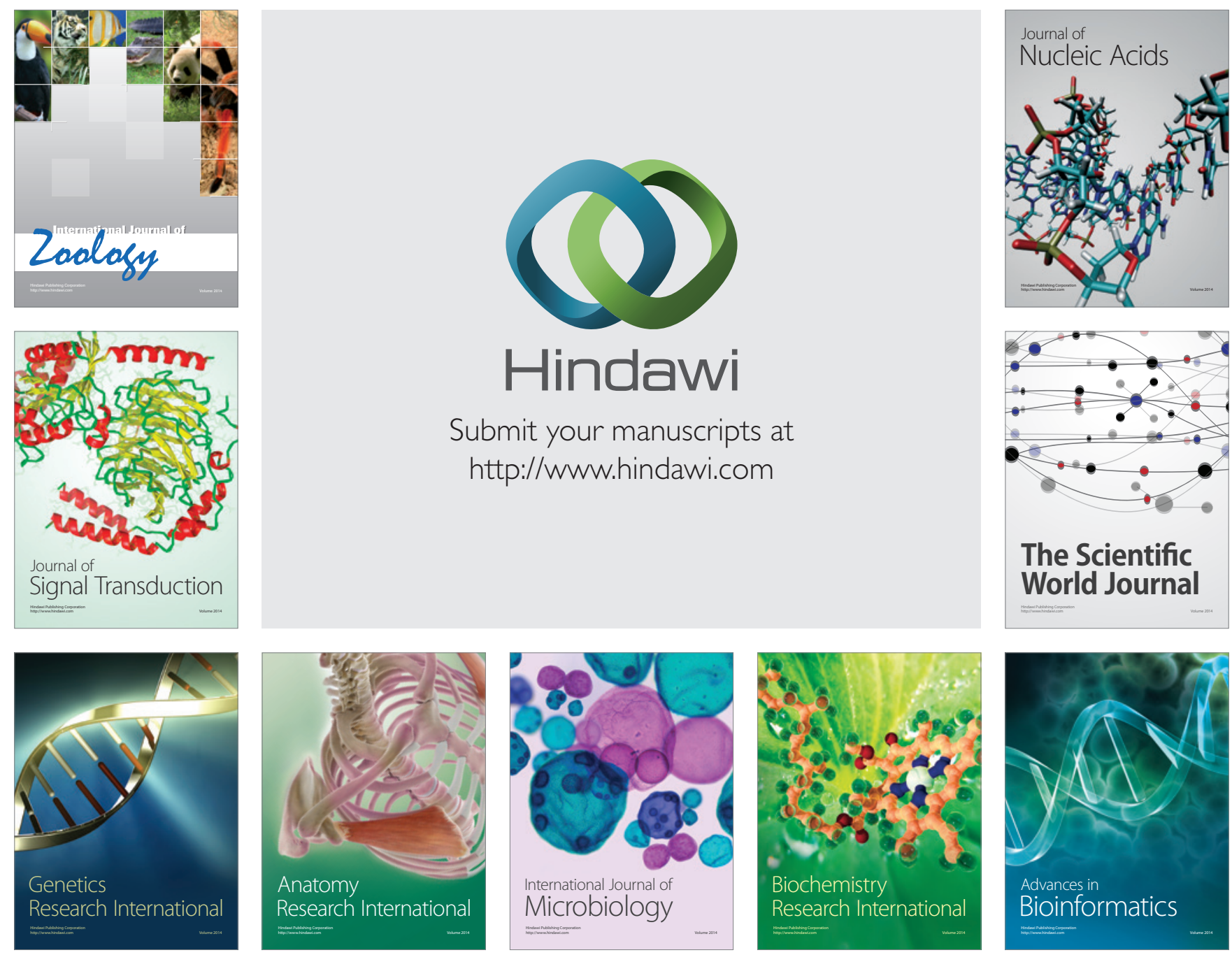

The Scientific World Journal
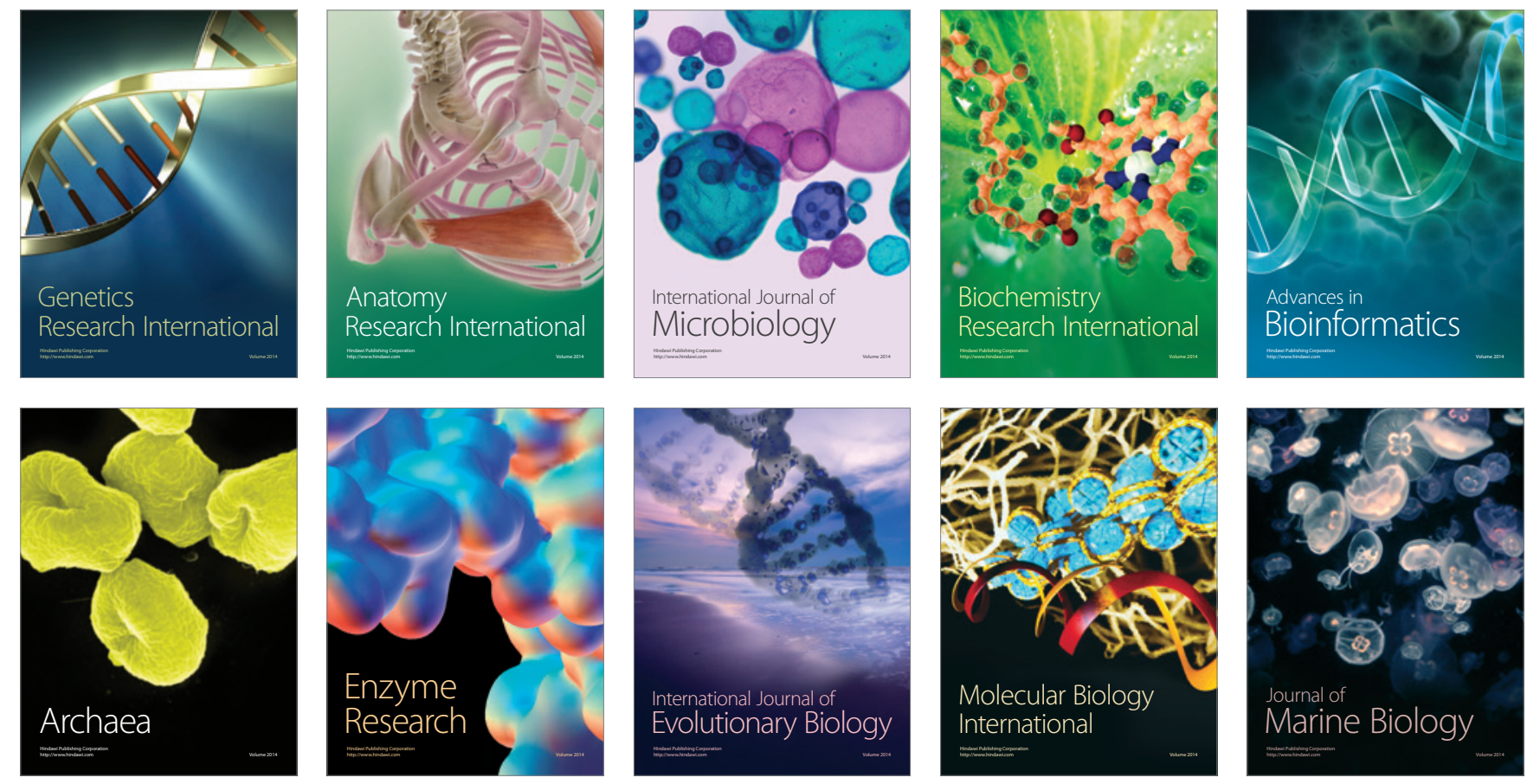